\title{
Do Economic Complexity and Strong Institutions Affect Income Inequality?
}

Rudy Hendra Prasetiya ${ }^{1}$

Corresponding author. Email: rudyhendra@iuj.ac.jp

Submitted: 2021-08-13| Accepted: 2021-12-15 | Published: December $31^{\text {st }} 2021$

\begin{abstract}
Advanced countries tend to produce complex goods that help the economy to grow. This study investigates the relationship of a country's sophisticated products and institutional indicators on income inequality. A cross-country OLS and fixed-effects estimate regression analysis show that countries with productive economic structures have less inequality. Meanwhile, three government indicators in accountability, political stability, and the rule of law show mixed results. Using the system generalized method of moments (GMM) to control the endogeneity, we find evidence of a causal link from economic complexity to income inequality in the short run. Meanwhile, the government's political stability is not a significant predictor.
\end{abstract}

Keywords: income inequality; economic complexity; institutions; two-step system GMM. 


\section{Introduction}

\subsection{Background of Problems}

One of the most prominent arguments behind what makes rich countries rich is that countries with better economic structures will thrive. Therefore, governments will have a better chance to grow. Thus, even though the inequality rate increases at the initial growth phase, it will eventually be reduced (Kuznets, 1955). Other researchers confirm the U-shaped Kuznets curves (Ahluwalia, 1977; Barro, 2008), while other scholars conclude that there is only a downward slope (Perotti, 1996). Besides the monetary instrument like the gross domestic product, several studies had a more nuanced explanation of a country's growth: its productive structure based on the composition of agriculture, manufacture, and service (Goodman \& Hirschman, 1959; Saviotti et al., 2020). However, the framework is too broad to explain income distribution (Hartmann et al., 2017).

Scholars have been trying to investigate more nuanced explanations. In the past decade, economic complexity has been popular than ever because it is a reliable predictor of economic growth. In addition, countries' advanced capability and basket in sophisticated products result in better income distribution (Hartmann, 2014; Hartmann et al., 2017; Hidalgo \& Hausmann, 2009; Lee \& Vu, 2020). Economic complexity (the level of commodities' sophistication produced and exported) can also foster knowledge across the country since it governs the know-how not captured by any formal education indicators (Bustos et al., 2012; Hidalgo \& Hausmann, 2009). Subsequently, economic complexity correlates with a country's level of poverty and per-capita income (Bourguignon, 2016; Wan et al., 2021).

Meanwhile, institutions are often left implicit despite their essential role in countries' economies (Acemoglu et al., 2014). North and Thomas's (1973) classical work argues that institutions are the fundamental determinant shaping a set of proximate determinants (total productivity, human capital, and accumulated physical capital) that contribute to economic development. Institutions act as catalysts for countries' development and are altered by skills and knowledge from the economic structure (North, 1990). Also, a complex economic structure correlates with better institutions and strong unionization (Hartmann, 2014).

Kuznets also argues that one must determine the pattern of institutions' distinctive and ways (1955). Growth per capita is not the sole determinant of the variety of inequality (J. Stiglitz et al., 2014; J. E. Stiglitz, 1996). Income distribution is also influenced by the country's set of human capital (Duflo, 2004; Saviotti et al., 2020), geography (Acemoglu \& Robinson, 2014; Rodrik, 2002), return on capital (Hausmann \& Rodrik, 2003), institutions (Acemoglu \& Robinson, 2014; Frieden et al., 2020), political stream (Audi \& Ali, 2019; Glaeser et al., 2004; Guo, 2009; Jones \& Olken, 2005; Perotti, 1996), and history (Acemoglu et al., 2012; Frieden et al., 2020). Complexity in the economy implies a country's ability to produce a diverse basket of products that are not ubiquitous in global trade. Some studies conclude that economic complexity is a strong determinant of inequality (Hartmann, 2014; Hartmann et al., 2017; Khan et al., 2020). Lee \& Vu argue that economic complexity is positively associated with income inequality (2020).

Despite the limitation, this paper investigates the causal impact between economic complexity (using Economic Complexity Index as a proxy), institutions, and income inequality by the argument that a country's productive capabilities (Hidalgo et al., 2007; Hidalgo \& Hausmann, 2009) and its institutional setting (Acemoglu et al., 2012, 2014; Kim et al., 2019; Rodrik, 2002). Thus, this study attempts to understand the impact of economic complexity and institutions on income inequality. The remainder of the thesis is organized as follows. The next chapter reviews the related literature. Chapter Three presents the overview of economic complexity and institutions. Chapter Four discusses the methodology. Chapter Five presents the data used in this study. Chapter Six covers the result and 
discussion regarding the correlation and causal impact of economic complexity and institutions on inequality. Lastly, Chapter Seven presents the conclusion.

\subsubsection{Economic Complexity}

Kuznets' inverted-U-shaped curve (1955) describing the relationship of the country's level on its average income and income inequality implies that income inequality will increase for a while before it is eventually reduced as the economy develops. The following works prove that this assumption does not hold in cross-country study with a dummy of Latin America countries (Deininger \& Squire, 1998), the study of East-Asian countries that reduce income inequality while growing to the more extensive economy (J. E. Stiglitz, 1996). Another study with policy differences in each country as an explanatory variable does not reaffirm the Kuznets curve (Kanbur, 2012). Interestingly, Piketty (2015) argues that the reduced inequality during the first half of the twentieth century was because of the natural income redistribution after two world wars and cannot be replicated in a globalized world.

Also, several studies argue that one must consider countries' growth rates and the type of growth and the institutions to explain the inequality (Acemoglu \& Robinson, 2014; Hartmann, 2014; J. Stiglitz et al., 2014). In other words, the GDP alone cannot fully explain economic development and inequality. Henceforth, scholars analyze the country's economic structures that might explain the country's growth and inequality.

Around a decade ago, Hidalgo and Hausmann (2009) proposed a method to measure a country's set of productive capabilities (non-tradeable) in a basket of tradeable products. Thus, an intertwining network of growth, economic development, and product composition in global trade can quantify a country's economy (Hidalgo \& Hausmann, 2009).

Hidalgo and Hausman (2009) composed a Revealed Comparative Advantage (RCA) measurement and argued that countries with high capabilities produce diverse and less ubiquitous goods. The complexity of a country's export highly predicts income level and is a helpful measurement of economic development. Economic complexity is calculated from the equation of diversity and ubiquity (Hidalgo \& Hausmann, 2009):

$$
\begin{gathered}
k_{c, n}=\frac{1}{k_{c, 0}} \sum_{p} M_{c p} \frac{1}{k_{c, 0}} \sum_{p} M_{c^{\prime} p} k_{c^{\prime}, n-2} \\
=\sum_{c^{\prime}} k_{c^{\prime}, n-2} \sum_{p} \frac{M_{c^{\prime} p} M_{c p}}{k_{c, 0} k_{p, 0}} \\
=\sum_{c^{\prime}} k_{c^{\prime}, n-2} \widetilde{M}_{c, c^{\prime}}^{C} \\
\widetilde{M}_{c, c^{\prime}}^{C} \equiv \sum_{c^{\prime}} \frac{M_{c^{\prime} p^{\prime}} M_{c p}}{k_{c, 0} k_{p, 0}}
\end{gathered}
$$

Where $M_{c^{\prime} p}=R C A_{c^{\prime} p}, M_{c p}=R C A_{c p}$, and $\widetilde{M}_{c, c^{\prime}}^{C}$ Denotes a matrix connecting countries exporting similar products (weighted by the inverse of a product's ubiquity).

In a vector notation, if $\vec{k}_{n}$ to be the vector whose $c$ th element is $k_{c, n}$,

$$
\vec{k}_{n}=\widetilde{M}_{c, c \prime}^{c} \times \vec{k}_{n-2}
$$

If $n$ goes to infinity, the equation becomes the distribution with a scalar factor:

$$
\widetilde{M}_{c, c \prime}^{C} \times \vec{k}=\lambda \vec{k}
$$

Subsequently, with the normalization of a country's diversity (Hartmann et al., 2017), the Economic Complexity Index (ECI) becomes: 


$$
E C I=\frac{K_{c}-\langle K\rangle}{s t d(K)}
$$

where $K_{c}$ is an eigenvector of $\widetilde{M}_{c, c}^{c}$. Therefore, Economic Complexity Index is defined as the eigenvector corresponding with the second largest eigenvalue is a vector of the $\widetilde{M}_{c, c}^{C}$ matrix ( Hausmann et al., 2014).

Subsequently, the economic complexity of the productive structure would support sustained growth and prosperity. As shown in Figure 1, countries with increasing economic complexity tend to reduce income inequality (Hartmann, 2014).

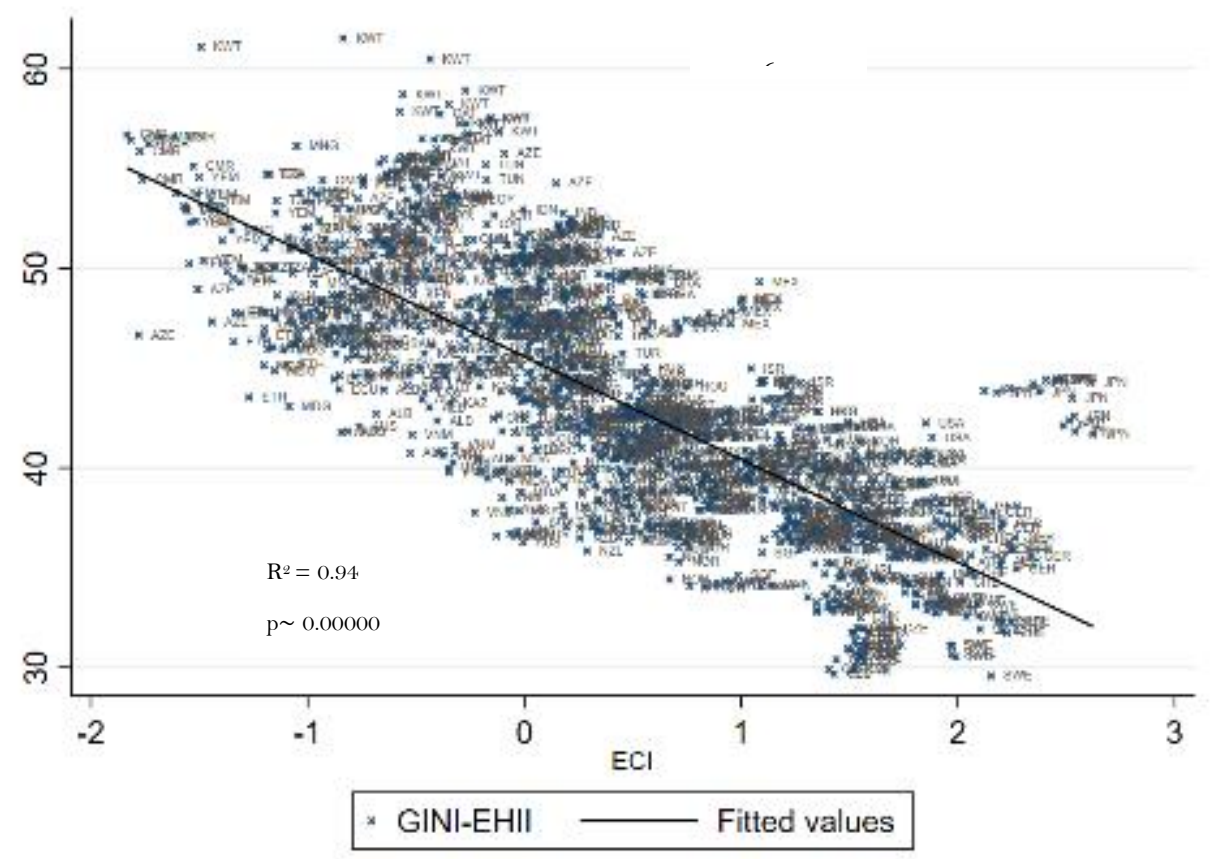

Figure 1. GINI-EHII and Economic Complexity Index (1996-2015)

Source: Author's computation.

As shown in Table 1, in 2016, the top five countries in Economic Complexity Index are Japan, Switzerland, Germany, South Korea, and Singapore. On the other hand, the bottom consists of Mauritania, the Democratic Republic of Congo, Guinea, Nigeria, and Papua New Guinea. Japan ranks as the most complex country during 2011-2018, with an ECI of more than 2.30. Japan's high ECI due to its diversification on export. Japan's export value was USD 944 billion, and its most significant exports are in moderate and high complexity products. Japan's main exported products in 2018 are cars (10.18\%) and information and communication technology (8.65\%) (Harvard's Growth Lab, n.d.). As a result, Japan and other top countries show a relatively consistent Economic Complexity Index. On the contrary, countries with low Economic Complexity Index are more likely to have more dynamic indices since their tradeable goods primarily consist of agricultural and less complex products. Consequently, their demands are characterized by a high degree of volatility. 
Table 1. Economic Complexity Rank (2011-2018)

\begin{tabular}{|c|c|c|c|c|c|c|c|c|c|}
\hline \multirow{2}{*}{$\begin{array}{l}2018 \\
\text { Rank }\end{array}$} & \multirow{2}{*}{ Country } & \multicolumn{8}{|c|}{ Economic Complexity Index (2011-2018) } \\
\hline & & 2011 & 2012 & 2013 & 2014 & 2015 & 2016 & 2017 & 2018 \\
\hline 1 & Japan & 2.35 & 2.33 & 2.33 & 2.30 & 2.44 & 2.49 & 2.44 & 2.43 \\
\hline 2 & Switzerland & 2.10 & 2.02 & 2.08 & 2.03 & 2.20 & 2.28 & 2.21 & 2.17 \\
\hline 3 & South Korea & 1.75 & 1.84 & 1.81 & 1.97 & 2.06 & 2.10 & 2.11 & 2.11 \\
\hline 4 & Germany & 2.05 & 1.97 & 2.10 & 2.11 & 2.25 & 2.26 & 2.16 & 2.09 \\
\hline 5 & Singapore & 1.81 & 1.76 & 1.84 & 1.75 & 1.87 & 1.93 & 1.88 & 1.85 \\
\hline 61 & Indonesia & -0.18 & -0.14 & -0.11 & -0.04 & -0.14 & -0.16 & -0.07 & -0.06 \\
\hline 64 & Russia & 0.05 & 0.05 & -0.01 & 0.07 & -0.01 & -0.03 & -0.07 & 0.02 \\
\hline 65 & Georgia & -0.03 & -0.13 & -0.08 & -0.01 & 0.17 & 0.10 & 0.12 & -0.04 \\
\hline 66 & Egypt & 0.01 & -0.25 & -0.08 & -0.24 & -0.18 & -0.23 & -0.28 & -0.04 \\
\hline 68 & Tanzania & -0.57 & -0.49 & -0.65 & -0.91 & -0.87 & -0.99 & -0.92 & -0.09 \\
\hline 69 & Mauritius & -0.07 & -0.10 & -0.10 & -0.06 & -0.17 & -0.34 & -0.23 & -0.17 \\
\hline 129 & Cameroon & -0.52 & -1.01 & -0.93 & -0.74 & -0.90 & -1.12 & -1.01 & -1.60 \\
\hline 130 & Papua New Guinea & -1.16 & -1.04 & -1.50 & -1.56 & -1.83 & -1.80 & -1.62 & -1.68 \\
\hline 131 & Angola & -1.60 & -1.61 & -1.28 & -1.55 & -1.25 & -1.16 & -1.60 & -1.71 \\
\hline 132 & $\begin{array}{l}\text { Democratic } \\
\text { Republic of the } \\
\text { Congo }\end{array}$ & -1.33 & -1.57 & -1.46 & -1.61 & -1.68 & -1.64 & -1.58 & -1.80 \\
\hline 133 & Nigeria & -1.88 & -1.61 & -1.68 & -1.90 & -2.18 & -1.79 & -1.76 & -1.90 \\
\hline
\end{tabular}

Source: Harvard's Atlas of Economic Complexity

\subsubsection{Institutional Indicators}

As mentioned earlier, pundits argue that a country's type of growth and institutional settings influence inequality because they govern law, regulations for development, property rights, and accountability (Rodrik, 2002). In other words, institutions play a vital role in either promoting or halting economic achievement. Even long-embodied traces from the previous colonializations also correlates with nowadays economy (Acemoglu et al., 2012).

Besides, there is a dichotomy in treating institutions as exogenous or endogenous. On the one hand, the institution's broad dimension is isolated to treat other economic determinants (Hall \& Jones, 1999; Knack \& Keefer, 1995). On the other hand, Acemoglu et al. (2014) argue that treating institutions and human capital as exogenous entails omitted variable bias. Therefore, treating institutional determinants and human capital as endogenous results in robust estimates of the long-run economic determinants (Acemoglu et al., 2014). However, this study assumes that the three governance indicators: government's voice and accountability, political stability and absence of violence/terrorism, and the rule of law are exogenous only in the static panel data model.

Generally, measuring the strength of institutions is not easy. Sometimes, the symptoms of weak governance are more evident. For example, weak institutions could lead a country into an inadequate macroeconomic stabilization, inappropriate trade, ineffective bureaucracy, and policies favoring a particular group (Artadi \& Sala-i-martin, 2003; Bates, 
2013; Collier \& Gunning, 1999; Easterly \& Levine, 1997; Sachs \& Warner, 1997); ethnic and social clashes, conflicts and civil wars (Acemoglu et al., 2012; Collier \& Gunning, 1999; Easterly \& Levine, 1997; Rodrik, 2002). Consequently, the country will have a slim chance to develop and a stagnant economy, thus, exacerbating the inequality.

Complex exported products, better institutions, and an inclusive economy are likely associated in advanced countries (Hartmann et al., 2017). Furthermore, he argues that institutions coexisting with productive economic structures might help explain variations in income inequality. Countries exporting more complex products tend to be more inclusive and have lower income inequality rates than countries that export less complex goods. Moreover, those who engage in the export markets learn global standards and manufacturing technology (J. E. Stiglitz, 2018).

\subsection{Research Question}

Studies about productive structures coexisting with institutions that promote inclusiveness have increased (Frieden et al., 2020; Hartmann et al., 2017; Lee \& Vu, 2020). The study of Hartman et al. (2017) and its replication (Lee \& Vu, 2020) investigate economic complexity and income inequality using OLS and fixed-effects regression. Both papers result in decreasing income inequality as the country achieves a higher ECI. Lee and Vu (2020) then tried to control the potential endogeneity bias using the system generalized method of moments (GMM). They found that for any increase in economic complexity, the inequality is also higher.

The nature of institutions in previous literature varies, whether it is endogenous or exogenous. Moreover, Gini and GDP are commonly agreed as time-persistent. Therefore, this study, firstly, treats institutions as the exogenous variables in the specification with OLS and fixed-effects estimates and as the endogenous later in the dynamic panel data model. Secondly, since Gini's and GDP's persistence, the third model in this paper uses lagged-Gini and lagged-value of the per-capita GDP and its squared term (the so-called Kuznets Curve) in the dynamic panel data model. Finally, because of the endogeneity and serial correlation bias problem, this paper investigates the causal effect on the determinants using a two-step system GMM with the altered specification.

From the previous discussion, this study proposes the following hypotheses:

H1. Economic complexity negatively affects income inequality.

H2. Strong institutions negatively affect income inequality.

\subsection{Logical Framework}

The general view has been those productive structures and institutions within might have a bifurcating impact on inequality. They can be more beneficial for a particular class while not helping the lower level, vice versa. Economic complexity will reduce income inequality by rationalizing that complexity comes from a technological advancement that promotes growth (P. Romer, 1990).

A country will obtain new accumulated capabilities to produce sophisticated products. During this phase, the higher the human capital, the faster countries' upgrade in production capability (Acemoglu et al., 2014; Hartmann et al., 2017). Consequently, human capital will also be accumulated and foster complexity to be sustainable (Hartmann, 2014; Hausmann et al., 2014; Hidalgo \& Hausmann, 2009). Moreover, human capital is vital in explaining countries' income disparity (D. Romer \& Chow, 1996).

Following that, a country's capability to produce and export goods will allow incomegenerating and income distribution (Hartmann et al., 2017). However, these sequences might entail a wider inequality gap since technological change provides more utility for high- and middle-class firms. Moreover, the lower class will need some time to accumulate 
knowledge and know-how before joining high-paying jobs. Significantly, countries' capability to make the growth inclusive heavily depends on their institutions.

\section{Methods/Methodology}

This section describes the methods used in this study. The author needs to describe the reasons used to justify the use of the method and adequately describe it and why other alternative methods are not selected. This section is also used to describe the types and sources of data used and the analysis process.

This section describes the methods used in this study. The author needs to describe the reasons used to justify the use of the method and adequately describe it and why other alternative methods are not selected. This section is also used to describe the types and sources of data used and the analysis process.

\subsection{Static Panel Data Model}

The specification follows Hartmann et al. (2017) in regressing income inequality against economic complexity, government's voice and accountability, political stability and absence of violence/terrorism, the rule of law, and per-capita GDP Purchasing Power Parity and its squared term, population, and years of schooling. However, the previous work includes three more dimensions of governance: regulatory quality, institutions' effectiveness, and control of corruption. Because of the multicollinearity problem, this study drops those institutions' indicators and keeps the other three. The empirical models presented as:

$$
\begin{gathered}
\operatorname{GINI}_{i, t}=\beta_{0}+\beta_{1} E_{C I_{i, t}}+\beta_{2} \text { govva }_{i, t}+\beta_{3} \text { govpsnv }_{i, t}+\beta_{4} \text { govrol }_{i, t}+\beta_{5} \operatorname{lngdpp}_{i, t}+ \\
\beta_{6} \operatorname{Lngdppcs}_{i, t}+\beta_{7} \operatorname{lnpop}_{i, t}+\beta_{8} \text { educ }_{i, t}+\varepsilon_{i}(5)
\end{gathered}
$$

where $i$ denotes country $i(i=1,2, \ldots, 83), t$ for the year $(t=1,2, \ldots ., 20)$, GINI represents Gini coefficient estimates, $E C I$ for Economic Complexity Index, govva indicates the government's voice and accountability, govpsnv for its political stability and absence of terrorism/violence, and govrol for the rule of law. Following that, $\ln G D P P C$ and $\ln G D P P C s q$ for natural log of per capita income and its squared term, Educ for n years of schooling, $\ln P o p$ for natural $\log$ of population, and $\varepsilon_{i}$ as the error term.

Thus, this model tries to measure the correlation of a country's product mix and its institutions' dimensions on income inequality. Equation 5 will also estimate the possibility that the human capital, income, and governance indicators in high- and middle-and-lowincome country groups have distinctive impacts on the Gini.

A country's economic complexity measured with $E C I$ is expected to associate with income inequality negatively. Three institutions' dimensions: government's voice \& accountability, political stability \& absence of violence, and the rule of law is perceived as a catalyst of a country's economy (North, 1990). In other words, a country with more sophisticated products and better institutions is expected to have lower income inequality.

Furthermore, this study also assumes that the error terms are time-invariant and within-country observed. Therefore, the regression model using fixed-effect estimations will be:

$$
\begin{aligned}
\operatorname{GINI}_{i, t}= & \beta_{0}+\beta_{1} E \mathrm{CI}_{i, t}+\beta_{2} \text { govva }_{i, t}+\beta_{3} \text { govpsnv }_{i, t}+\beta_{4} \text { govrol }_{i, t}+\beta_{5} \operatorname{lngdppc}_{i, t}+ \\
& \beta_{6} \text { Lngdppcsq }_{i, t}+\beta_{7} \operatorname{lnpop}_{i, t}+\beta_{8} \text { educ }_{i, t}+\propto_{i}+u_{i, t}
\end{aligned}
$$

where $i$ denotes country $i(i=1,2, \ldots, 83), t$ for the year $(t=1,2, \ldots \ldots, 20)$, GINI for Gini coefficient estimates, ECI for Economic Complexity Index, govva for the government's voice and accountability, govpsnv represents political stability and absence of terrorism/violence, govrol for the rule of law. Following that, $\operatorname{lnGDPPC}$ and $\ln G D P P C s q$ 
for natural log of per capita income and its squared term, Educ for n years of schooling, lnPop for natural $\log$ of population, $\propto_{i}(i=1,2, \ldots, 83)$ denotes the unknown intercept for each entity, and $u_{i, t}$ is the error term.

\subsection{Dynamic Panel Data Model}

This study suspects this regional dataset in the macroeconomic context might have weakly exogenous regressors and serially correlated errors (S. Bond, 1991; Judson \& Owen, 1999). Lagged-Gini might not be exogeneous since it might determine coefficients in the upcoming $t$ and move slowly during the given period. If so, then the strict exogeneity assumption no longer holds. This endogeneity bias problem motivates us to employ a dynamic panel data estimation. Also, within transformation or LSDV estimates does not eliminate dynamic panel bias (Blundell \& Bond, 1998; S. R. Bond, 2002; Nickell, 1981) or is no longer consistent since

$$
\operatorname{plim}_{N \rightarrow \infty, T \text { fixed }} \gamma L S D V \neq \gamma
$$

Hence, the later model will be:

$$
\begin{aligned}
& \operatorname{GINI}_{i, t}=\beta_{0}+\beta_{1} \text { IINI }_{i, t-1}+\beta_{2} E \mathrm{CI}_{i, t}+\beta_{3} \text { govpsnv }_{i, t}+\beta_{4} \operatorname{lngpp}_{i, t}+ \\
& \beta_{5} \operatorname{lngdppcs} q_{i, t}+\beta_{6} e d u c_{i, t}+\delta_{i}+\mu_{t}+v_{i, t}
\end{aligned}
$$

where $i$ represents country $i(i=1,2, \ldots, 84)$ in year $t(t=1,2, \ldots \ldots, 20)$, . GINI fir Gini coefficient estimates, ECI for Economic Complexity Index, govva denotes voice and accountability, govpsnv for political stability and absence of terrorism/violence, and govrol for the rule of law. Lagged variables $G I N I_{i, t-1}$ represents the lagged value of Gini in $t-1$. Control variables are $\ln G D P P C$ and $\ln G D P P C s q$ for the natural log of per capita income and its squared term. Another controlling variable is Educ for n years of schooling. Following that, $\delta_{i}$ is the country fixed effects, $\mu_{t}$ is the time effect, and $v_{i, t}$ is the error term.

As the canonical Kuznets curve suggests that growth widens the income distribution gap but, eventually, shrinks it (Kuznets, 1955), countries' productive structures might indicate the population's accumulated knowledge know-how (Hausmann et al., 2014). Inequality, then, is expected to be lower as the population grows, amass knowledge, and join a bigger economy.

Therefore, this study treats per-capita GDP as endogenous (D. Romer \& Chow, 1996) and use government's political stability only as an institutional proxy for any civil tension (Kaufmann et al., 2009) that might be a consequence when income distribution did not take place across all classes under a bigger economy ${ }^{2}$ (Kuznets, 1955). In addition, this model assumes ECI, political stability, GDP, and education as the endogenous variable in the twostep system GMM regression and uses them as instrumental variables. Finally, we choose two and up for the lagged variable of ECI, political stability, GDP, and education, since it is the standard treatment for an endogenous variable (Roodman, 2009).

Due to the risk of instrumental proliferation that might weaken the Hansen $J$ test, the population is no longer included in the latest model. Moreover, the specification assumes no individual correlation in the idiosyncratic disturbances and uses Windmeijer-corrected robust estimates of the coefficient of standard errors and orthogonal deviations. Also, as argued by Roodman (2009), including the year dummy can strengthen the assumption?

\footnotetext{
${ }^{2}$ This study specifies government's political stability, economic complexity, GDP, and $n$ years of schooling as instrumental variables as they are assumed to be endogenous.

${ }^{3}$ For further discussion on two-step system GMM estimates with corrected standard errors, see Roodman (2009).
} 


\subsection{Data}

\subsubsection{Income Inequality: GINI - Estimated Household Income Inequality}

Following the study of Hartman et al. (2017), the dependent variable, the Gini coefficient, is a measure of income inequality from the GINI EHII (Estimated Household Income Inequality) dataset ${ }^{4}$ on a 0-to-1 scale (Galbraith et al., 2014). Therefore, this paper uses the dataset comprising cross-sectional of 83 countries from 1996-2015 as an income inequality measure ${ }^{5}$. The dataset is relatively comprehensive (Hartmann et al., 2017) since it measures global pay inequality and uses international data sets from Global Comparisons and UNIDO's industrial statistics. In addition, the University of Texas Inequality Project dataset has been updating the dataset since the 1970s. However, the limitation of its dataset, like the World Bank's data, is the spareness in low-income countries.

\subsubsection{Economic Complexity}

The Economic Complexity Index (ECI) was derived from the Atlas of Economic Complexity from Harvard's Growth $\mathrm{Lab}^{6}$. The previous study uses the data economic complexity index from MIT's Observatory of Economic Complexity (Hartmann et al., 2017; Hausmann et al., 2014; Lee \& Vu, 2020; Simoes \& Hidalgo, 2011). Harvard's Growth Lab uses a data cleaning method for inconsistencies based on import-export value and index of country's reliability. ECI is computed from export data connecting countries to the products they have Revealed Comparative Advantages (RCA) (Hidalgo \& Hausmann, 2009). Therefore, as shown in Equation 4, ECI combines the ubiquity and diversity of a country's products. A country is complex if it exports a sophisticated and diverse range of products (high diversity), including products exported by few other countries (low ubiquity).

\subsubsection{Institutional Indicators}

Pundits argue that there is a broad spectrum of institutions' roles and impact. This study exploits three governance dimensions from the Worldwide Governance Indicators (WGI) proxy for institutions ${ }^{7}$. This paper uses the government's voice and accountability, political stability and absence of violence, and the rule of law. The WGI, however, consists of six governance indicators for more than 200 countries since 1996. The WGI dataset is a composite scoring from 30 underlying data sources using the unobserved components model. The dataset offers a broader tool in cross-country comparison and understanding the trend and emphasizes the state's capability, accountability to its people, and the operation under the law (Kaufmann et al., 2009). The WGI comes from surveys of households and firms, commercial business information providers, non-governmental organizations, and public sector institutions. This dataset is aggregated from many individual data sources on government perception using the unobserved components model.

First, the government's voice and accountability indicator captures media and people's freedom in expression, association, participation, and voting. Its setting represents the openness and inclusiveness of a state. Second, the political stability and absence of violence/terrorism imply whether a country's regime is stable or not. Political stability

\footnotetext{
${ }^{4}$ The paper of Galbraith et al. consists of 149 countries covering year 1963-2015. The study also includes the updated dataset from University of Texas Inequality Project https://utip.gov.utexas.edu/.

${ }^{5}$ High-income countries: Poland, Portugal, Romania, Slovakia, Slovenia, Spain, Sweden, Switzerland, United Kingdom, Chile, Panama, Uruguay, Israel, Kuwait, Oman, Qatar, Saudi Arabia, Canada, United States of America; upper-middle-income countries: China, Indonesia, Malaysia, Thailand, Albania, Azerbaijan, Bulgaria, Georgia, Kazakhstan, Russian Federation, Turkey, Argentina, Brazil, Colombia, Costa Rica, Ecuador, Jamaica, Mexico, Paraguay, Peru, Iran, Jordan, South Africa; lower-middle-income countries: Mongolia, Philippines, Vietnam, Republic of Moldova, Ukraine, Egypt, Morocco, Tunisia, India, Pakistan, Sri Lanka, Cameroon, Kenya, Senegal, United Republic of Tanzania; low-income countries: Yemen, Ethiopia, Madagascar.

6 The Atlas of Economic Complexity. Harvard's Growth Lab. (atlas.cid.harvard.edu/)

7 The World Bank's Worldwide Governance Indicators. (https://info.worldbank.org/governance/wgi/)
} 
provides a country's economic chance to grow. In contrast, warring tribes, social tensions, political violence, and terrorism make the government vulnerable to be overthrown. Therefore, ideal conditions to develop the economy would be fulfilled. Third, the rule of law captures institutions' confidence in abiding by the law, enforcing contracts, property rights, police and court's integrity, and the likelihood of crime and violence.

The WGI dataset provides a detailed and structured process of governance of each country. The spareness data in government indicators was treated by calculating the baseline's value and the end line ${ }^{8}$. However, the dataset's constraint needs deeper contextual investigation to explain the structural change within a country. The time constraint in the model, from 1996-2015, is also because of the data availability of the WGI dataset.

\subsubsection{Controlling Variables}

Controlling variables are the gross domestic product per capita at Purchasing Power Parity in constant 2010US\$, its squared term, country's population, and years of schooling from the World Bank ${ }^{9}$. These variables were also used in the study of Hartmann et al. (2017), and altogether with ECI, explain the cross-countries difference in inequality. The data covers 83 observed countries, mainly due to adjustment to the limitation on Gini data.

\subsubsection{Summary Statistics}

The average Gini coefficient is 0.43 on a scale of 0 to 1 , slightly lower than the neutral value of 0.50 (Table 2). Economic Complexity Index's scale is from -6.00 (less complex) to 6.00 (most complex). The government's accountability, political stability, and the rule of law range from -2.5 (weak) to 2.5 (strong) government's performance; overall, governments' performances are slightly above the neutral value.

Table 2. Summary Statistics of Variables in Regressions

\begin{tabular}{|l|r|r|r|r|r|}
\hline \multicolumn{1}{|c|}{ Variable } & \multicolumn{1}{c|}{ Obs. } & \multicolumn{1}{c|}{ Mean } & \multicolumn{1}{c|}{ SD } & \multicolumn{1}{c|}{ Min } & Max \\
\hline Income Inequality & 1310 & 0.43 & 0.06 & 0.30 & 0.62 \\
\hline Economic complexity & 1310 & 0.45 & 0.92 & -1.83 & 2.62 \\
\hline Government's accountability and voice & 1310 & 0.41 & 0.89 & -1.82 & 1.80 \\
\hline $\begin{array}{l}\text { Political stability and absence of } \\
\text { violence/terrorism }\end{array}$ & 1310 & 0.20 & 0.91 & -2.43 & 1.76 \\
\hline The rule of law & 1310 & 0.48 & 0.95 & -1.50 & 2.10 \\
\hline GDPPC-PPP, log & 1310 & 9.24 & 1.33 & 5.23 & 11.42 \\
\hline GDPPC-PPP, squared, log & 1310 & 87.10 & 23.84 & 27.39 & 130.53 \\
\hline Population, log & 1310 & 16.56 & 1.74 & 9.74 & 21.01 \\
\hline Years of schooling & 1310 & 9.37 & 2.65 & 1.00 & 14.10 \\
\hline
\end{tabular}

\subsubsection{Research Limitations}

This study is a part of social science and is based on challengeable assumptions and might be false. This thesis is limited to study 83 countries given the year 1996-2015 on the dependent variable, income inequality and independent variables, economic complexity, and institutions. This study concerns the causality of the determinant variables and does not

\footnotetext{
${ }^{8}$ The World Bank's data on Governance Indicators was biannual up until early 2002.

${ }^{9}$ The World Bank Open Data (https://data.worldbank.org/)
} 
consider any economic crisis shock during the period. Even though we tried to solve the endogeneity problem, we do not entirely address potential random measurement errors for economic complexity, institutions, and income inequality.

\section{Results and Discussions}

This chapter presents results and analyses the association of economic complexity, government's voice and accountability, political stability, and absence of violence/terrorism, the rule of low on Gini coefficient. Due to Gini data's spareness, this study only uses 83 countries that make up $85,57 \%$ of the world population in 2015 . The observed sample consists of four income level groups, namely high-income (50.60\%), upper-middle-income (27.71\%), lower-middle-income (18.07\%), and low-income countries $(3.61 \%)^{10}$.

To begin with, the OLS estimates regression and fixed-effect estimation are used to analyze the impact of economic complexity and institutional variables on income inequality. Following that, the dynamic data panel model with the two-step system GMM estimations presents the impact of independent variables on the inequality with some additional assumptions to solve the endogeneity and serial correlation bias problem.

\subsection{Fit of Goodness}

Firstly, OLS estimates result in the F-test value 0.0000 with $\mathrm{R}^{2}$, and adjusted $\mathrm{R}^{2}$ are 0.680 and 0.679 , respectively. Thus, the variance of the independent variables together can explain around $68 \%$ of the dependent variable. Secondly, the Fixed-effects estimates result in $0.9379 \mathrm{R}^{2}$ and 0.9333 adjusted $\mathrm{R}^{2}$ and explain $93 \%$ of the Gini's variance. Lastly, the twostep system GMM's result fails to reject the Hansen $J$ test and AR(2) test, thus validating the instruments and model specifications.

\subsection{Ordinary Least Squares Estimates}

The OLS estimates from Equation 5 result in a strong negative effect of economic complexity and institutional indicators on income inequality. Also, the OLS regression supports the Kuznets Curve. As shown in pooled-regression OLS (Table 3), the economic complexity and two institutional indicators in political stability and government's voice and accountability are statistically significant at a $1 \%$ level in all models. Moreover, countries with complex productive structures, better voice, accountability, stabilized political condition, and a sound ordinance has less inequality. Meanwhile, the rule of law is statistically significant at a $10 \%$ level.

${ }^{10}$ Based on the 2020 World Bank's Country Classification by Income Level. 
Table 3. OLS Regression Result (Dependent Variable: GINI): Pooled

\begin{tabular}{|c|c|c|c|c|c|c|}
\hline & (1) & (2) & (3) & (4) & (5) & (6) \\
\hline VARIABLES & GINI & GINI & GINI & GINI & GINI & GINI \\
\hline \multirow[t]{2}{*}{ Economic Complexity Index } & $-0.035 * * *$ & & $-0.043^{* * *}$ & $-0.032 * * *$ & $-0.034^{* * * *}$ & $-0.040^{* * *}$ \\
\hline & $(0.002)$ & & $(0.002)$ & $(0.002)$ & $(0.002)$ & $(0.002)$ \\
\hline $\begin{array}{l}\text { Government's Voice and } \\
\text { Accountability }\end{array}$ & $\begin{array}{l}-0.008^{* * *} \\
(0.002)\end{array}$ & $\begin{array}{l}-0.017^{* * *} \\
(0.002)\end{array}$ & & $\begin{array}{l}-0.009^{* * *} \\
(0.002)\end{array}$ & $\begin{array}{l}-0.001^{* * * *} \\
(0.002)\end{array}$ & $\begin{array}{l}-0.011^{* * *} \\
(0.002)\end{array}$ \\
\hline $\begin{array}{l}\text { Political Stability \& Absence } \\
\text { of Violence/Terrorism }\end{array}$ & $\begin{array}{l}-0.016^{* * *} \\
(0.002)\end{array}$ & $\begin{array}{l}-0.018^{* * *} \\
(0.002)\end{array}$ & & $\begin{array}{l}-0.014^{* * * *} \\
(0.002)\end{array}$ & $\begin{array}{l}-0.016^{* * * *} \\
(0.002)\end{array}$ & $\begin{array}{l}-0.014^{* * * *} \\
(0.002)\end{array}$ \\
\hline \multirow[t]{2}{*}{ The Rule of Law } & $-0.005^{*}$ & $-0.011 * * *$ & & 0.001 & $-0.005^{*}$ & -0.005 \\
\hline & $(0.003)$ & $(0.003)$ & & $(0.002)$ & (0.003) & $(0.003)$ \\
\hline \multirow{2}{*}{$\begin{array}{l}\text { Per-capita GDP 2010-PPP, } \\
\text { Log }\end{array}$} & $0.036^{* * * *}$ & $0.024 * *$ & $0.061^{* * * *}$ & & $0.036^{* * * *}$ & 0.016 \\
\hline & $(0.010)$ & $(0.011)$ & $(0.010)$ & & $(0.010)$ & $(0.010)$ \\
\hline $\begin{array}{l}\text { Per-capita GDP 2010-PPP, } \\
\text { Log, squared }\end{array}$ & $\begin{array}{l}-0.001 * * \\
(0.001)\end{array}$ & $\begin{array}{l}-0.001 \\
(0.001)\end{array}$ & $\begin{array}{l}-0.003^{* * *} \\
(0.001)\end{array}$ & & $\begin{array}{l}-0.001 * * \\
(0.001)\end{array}$ & $\begin{array}{l}-0.000 \\
(0.001)\end{array}$ \\
\hline \multirow[t]{2}{*}{ Population, Log } & 0.000 & $-0.004 * * *$ & $0.003^{* * * *}$ & -0.000 & & $0.002^{* * * *}$ \\
\hline & $(0.001)$ & $(0.001)$ & $(0.001)$ & $(0.000)$ & & $(0.001)$ \\
\hline \multirow[t]{2}{*}{ Years of Schooling } & $-0.005 * * *$ & $-0.009^{* * *}$ & $-0.006^{* * * *}$ & $-0.004 * * *$ & $-0.005^{* * * *}$ & \\
\hline & $(0.001)$ & $(0.001)$ & $(0.001)$ & $(0.005)$ & $(0.001)$ & \\
\hline \multirow[t]{2}{*}{ Constant } & $0.297^{*} * *$ & $0.463^{* * * *}$ & $0.189^{* * * *}$ & $0.487 * * *$ & $0.301 * * *$ & 0.326 **** \\
\hline & $(0.045)$ & $(0.050)$ & $(0.045)$ & $(0.014)$ & $(0.042)$ & $(0.046)$ \\
\hline Observations & 1,310 & 1,312 & 1,310 & 1,322 & 1,310 & 1,310 \\
\hline R-squared & 0.680 & 0.593 & 0.638 & 0.663 & 0.680 & 0.659 \\
\hline Number of countries & 83 & 83 & 83 & 83 & 83 & 83 \\
\hline F-Stat & 346.2 & 271.5 & 458.7 & 431.6 & 396 & 359.6 \\
\hline Prob $>$ F & 0.000 & 0.000 & 0.000 & 0.000 & 0.000 & 0.000 \\
\hline Degree of Freedom & 1302 & 1304 & 1304 & 1304 & 1315 & 1302 \\
\hline
\end{tabular}

Note: standard errors in parentheses $* * * \mathrm{p}<0.01$, ** $\mathrm{p}<0.05,{ }^{*} \mathrm{p}<0.1$

Ceteris paribus, 0.035 units decrease of inequality in the short run is associated with 1 unit increase in ECI. Holding other variables fixed, every additional unit in government accountability, political stability, and the ordinance is associated with inequality reduction by $0.008,0.016$, and 0.005 units. Inequality increase as much as 0.036 units are associated with a $1 \%$ increase in per-capita GDP. The result reaffirms the work of Hartman et al. (2017) and argues that complexity in productive structures provides accumulated knowledge and skill, job opportunity, and subsequently, sustained income. The result contradicts the previous study that the Kuznets Curve is less noticeable if not controlling the economic complexity. However, the Kuznets Curve is more noticeable in the model without controlling institutional variables. 
An additional exercise is conducted to analyze the estimation of high-income countries and countries that are not (Table 4 and Figure 3). Economic Complexity Index, government's accountability, and political stability are statistically significant at $1 \%$. The rule of law is only statistically significant at $5 \%$ in middle- and low-income countries. A oneunit increase in Economic Complexity Index is associated with inequality reduction as much as 0.033 for high-income countries and 0,036 for mid-and low-income countries, holding all variables constant $(\mathrm{p}<0.01)$. Political stability and the absence of violence and terrorism have a larger magnitude on the high-income countries. For each $1 \%$ increase in per-capita GDP, inequality in the middle- and low-income countries increase 0.066 units, ceteris paribus. Conversely, a $1 \%$ increase in high-income countries' GDP correlates with inequality's decreasing unit as much as 0.430 .

Table 4. OLS Regression Result (Dependent Variable: Gini): Income Level Sub-sample

\begin{tabular}{|c|c|c|c|}
\hline \multirow{3}{*}{ Variables } & $\begin{array}{l}\text { High-income } \\
\text { countries }\end{array}$ & $\begin{array}{l}\text { Middle- and } \\
\text { low-income } \\
\text { countries }\end{array}$ & All samples \\
\hline & (1) & (2) & (3) \\
\hline & Gini & Gini & Gini \\
\hline \multirow[t]{2}{*}{ Economic Complexity Index } & $-0.033^{*} * *$ & $-0.036^{* * * *}$ & $-0.035^{* * * *}$ \\
\hline & $(0.004)$ & $(0.002)$ & $(0.002)$ \\
\hline $\begin{array}{l}\text { Government's Voice and } \\
\text { Accountability }\end{array}$ & $\begin{array}{l}0.017 * * * * \\
(0.003)\end{array}$ & $\begin{array}{l}-0.016 * * * * \\
(0.002)\end{array}$ & $\begin{array}{l}-0.008 * * * * \\
(0.002)\end{array}$ \\
\hline $\begin{array}{l}\text { Political Stability \& Absence of } \\
\text { Violence/Terrorism }\end{array}$ & $\begin{array}{l}-0.0159^{* * * *} \\
(0.003)\end{array}$ & $\begin{array}{l}-0.016^{* * * *} \\
(0.002)\end{array}$ & $\begin{array}{l}-0.016^{* * * *} \\
(0.002)\end{array}$ \\
\hline \multirow[t]{2}{*}{ The Rule of Law } & -0.000 & $-0.008^{*} *$ & $-0.005^{*}$ \\
\hline & $(0.005)$ & $(0.003)$ & $(0.003)$ \\
\hline \multirow[t]{2}{*}{ Per-capita GDP 2010-PPP, Log } & $-0.430^{* * * *}$ & $0.066^{* * * *}$ & $0.036^{* * * *}$ \\
\hline & $(0.109)$ & $(0.011)$ & $(0.010)$ \\
\hline $\begin{array}{l}\text { Per-capita GDP 2010-PPP, Log, } \\
\text { squared }\end{array}$ & $\begin{array}{l}0.025^{* * * *} \\
(0.006)\end{array}$ & $\begin{array}{l}-0.003 * * * * \\
(0.001)\end{array}$ & $\begin{array}{l}-0.001^{* *} \\
(0.000) \\
\end{array}$ \\
\hline \multirow{2}{*}{ Population, Log } & 0.000 & $0.003 * * * *$ & 0.000 \\
\hline & $(0.001)$ & $(0.001)$ & $(0.001)$ \\
\hline \multirow[t]{2}{*}{ Years of Schooling } & -0.000 & $-0.006 * * *$ & $-0.005 * * *$ \\
\hline & (0.001) & (0.001) & (0.001) \\
\hline \multirow[t]{2}{*}{ Constant } & $2.339^{* * * *}$ & $0.0923^{*}$ & 0.297 **** \\
\hline & $(0.461)$ & $(0.050)$ & $(0.045)$ \\
\hline Observations & 743 & 567 & 1,310 \\
\hline R-squared & 0.6955 & 0.3869 & 0.6804 \\
\hline Number of Countries & 42 & 41 & 83 \\
\hline F-Stat & 209.5 & 44.02 & 346.2 \\
\hline Prob $>$ F & 0.000 & 0.000 & 0.000 \\
\hline Degree of Freedom & 734 & 558 & 1301 \\
\hline
\end{tabular}

Note: standard errors in parentheses ${ }^{* * *} \mathrm{p}<0.01$, $^{*} \mathrm{p}<0.05,{ }^{*} \mathrm{p}<0.1$

It results in mixed evidence regarding the Kuznets' inverted U-shaped curve. In the short run, all regressors are statistically significant. However, per-capita GDP, its squared term, and state accountability have different signs in the two country groups. For highincome countries, the higher the GDP, the less the inequality (Table 4 Column 1 \& Figure 2). Similarly, better governance quality in accountability and capturing citizens' voices, 
surprisingly, expand the inequality. The result suggests that this institutions' dimension brings salient benefits for the fortunate people.

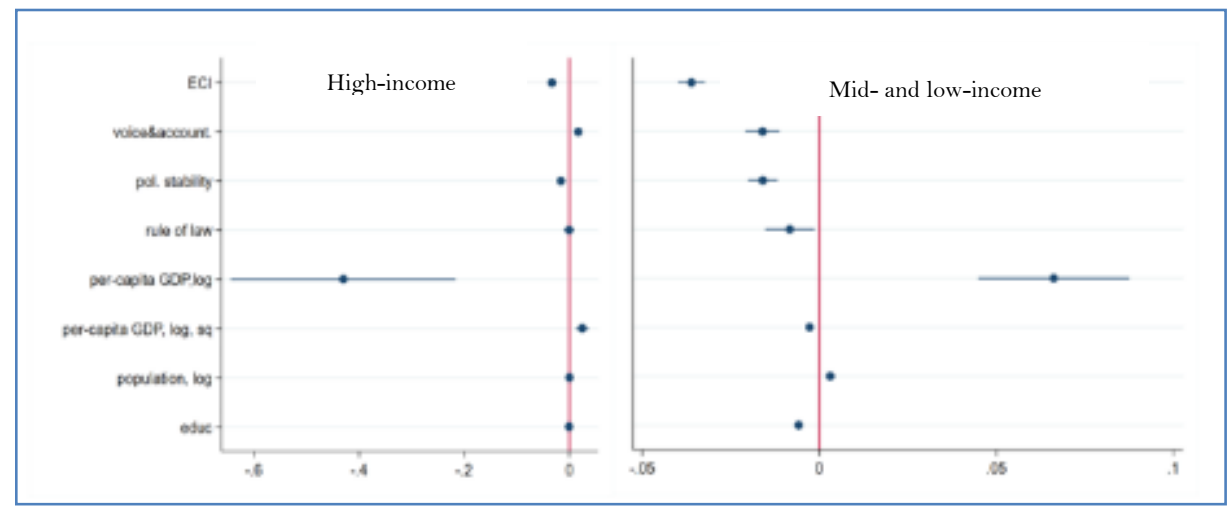

Figure 2. OLS Regression Result (Dependent Variable: Gini): Income Level Sub-samples

Source: Author's calculation

In contrast, middle- and low-income country experiences increased inequality for each increasing GDP. For the middle- and low-income countries, increasing income per capita and better government accountability widen the inequality gap. Meanwhile, higher GDP promotes income distribution through labor absorption in an advanced country with long years of schooling. It is in line with the idea that advanced countries had earlier industrialization (Acemoglu \& Robinson, 2014) to make the income distribution through labor absorption easier. The result also reiterates the study in South East Asian countries. An investment in human capital could prepare labor forces and minimize the inequality gap from a growing economy (J. E. Stiglitz, 1996).

Conclusively, the Kuznets curve is an inverted U-shaped curve, using 83-country samples from 1996-2015. Also, based on the sub-sample regression, this paper suggests that increasing GDP widens the inequality gap before it eventually promotes income distribution, confirming previous works from Kuznets (1995), Hartmann et al.(2017), and Lee and $\mathrm{Vu}(2020)$.

Furthermore, as shown in Table 4, institution's variables in accountability, political stability, and the rule of law are also sound predictors in explaining Gini. Without controlling economic complexity, government accountability, political stability, the rule of law, and education (denoting the increase in human capital) have a more significant coefficient on inequality. Human capital is statistically significant in all models $(p<0.01)$. This study argues that institutions, productive structures, and human capital can explain $68 \%$ of the samples' variance. It contradicts the previous studies that found that institutions are not significant determinants whenever the model using ECI and human capital is proxied by years of schooling (Hartmann et al., 2017) or tertiary education (Lee \& Vu, 2020). In subsample observation, the rule of law is more evident in the middle- and low-income countries. Also, strong ordinances are associated with better income distribution.

\subsection{Fixed Effect Estimates}

This study suspects that under the OLS estimates regression, independent variables are correlated with the error term. Fixed effects estimates model is more robust to such bias than the OLS estimation. To obtain an unbiased estimate of $\beta$, individual-time specificvarying covariates cannot be correlated with the time-constant error term (Woolridge, 2010). By assuming the error terms are time-invariant and within-country observed, this study uses the fixed-effect estimators to remove them. The fixed-effect panel regression will provide the inequality change variation across the countries. Moreover, the Hausman test's 
result rejects the null hypothesis that differences in the fixed-effect and random-effect estimations are systematic.

Table 5. Fixed-Effects Estimation Regression Result (Dependent Variable: GINI)

\begin{tabular}{|c|c|c|c|c|c|c|}
\hline & (1) & $(2)$ & (3) & (4) & $(5)$ & (6) \\
\hline VARIABLES & GINI & GINI & GINI & GINI & GINI & GINI \\
\hline \multirow[t]{2}{*}{$\begin{array}{l}\text { Economic Complexity } \\
\text { Index }\end{array}$} & $-0.014^{* * * *}$ & & $-0.013^{* * *}$ & $-0.012^{* * *}$ & $-0.014 * * * *$ & $-0.013^{* * *}$ \\
\hline & (0.003) & & (0.003) & $(0.003)$ & (0.003) & (0.003) \\
\hline $\begin{array}{l}\text { Government's Voice and } \\
\text { Accountability }\end{array}$ & $\begin{array}{l}0.011^{* * * *} \\
(0.003)\end{array}$ & $\begin{array}{l}0.009^{* * * *} \\
(0.003)\end{array}$ & & $\begin{array}{l}0.012^{* * * *} \\
(0.003)\end{array}$ & $\begin{array}{l}0.010^{* * * *} \\
(0.003)\end{array}$ & $\begin{array}{l}0.012^{* * * *} \\
(0.003)\end{array}$ \\
\hline $\begin{array}{ll}\text { Political Stability } & \& \\
\text { Absence } & \\
\text { Violence/Terrorism } & \end{array}$ & $\begin{array}{l}-0.003 \\
(0.002)\end{array}$ & $\begin{array}{l}-0.003 \\
(0.002)\end{array}$ & & $\begin{array}{l}-0.005^{* * * *} \\
(0.002)\end{array}$ & $\begin{array}{l}-0.003 * \\
(0.002)\end{array}$ & $\begin{array}{l}-0.004 * * \\
(0.002)\end{array}$ \\
\hline \multirow[t]{2}{*}{ The Rule of Law } & $-0.012^{* * * *}$ & $-0.012 * * *$ & & $-0.012 * * *$ & $-0.011^{* * * *}$ & $-0.013^{* * *} *$ \\
\hline & (0.003) & (0.003) & & $(0.003)$ & (0.003) & $(0.003)$ \\
\hline \multirow[t]{2}{*}{$\begin{array}{l}\text { Per-capita GDP 2010- } \\
\text { PPP, Log }\end{array}$} & $-0.146^{* * * *}$ & $-0.139 * * *$ & $-0.127 * * *$ & & $-0.138 * * *$ & $-0.160 * * *$ \\
\hline & $(0.021)$ & $(0.021)$ & $(0.021)$ & & $(0.021)$ & $(0.020)$ \\
\hline $\begin{array}{l}\text { Per-capita GDP 2010- } \\
\text { PPP, Log, squared }\end{array}$ & $\begin{array}{l}0.008^{* * *} \\
(0.002)\end{array}$ & $\begin{array}{l}0.007^{* * * *} \\
(0.001)\end{array}$ & $\begin{array}{l}0.006^{* * * *} \\
(0.001)\end{array}$ & & $\begin{array}{l}0.007^{* * * *} \\
(0.001)\end{array}$ & $\begin{array}{l}0.009^{* * * *} \\
(0.001)\end{array}$ \\
\hline \multirow[t]{2}{*}{ Population, Log } & $0.015^{* * *}$ & $0.017^{*} * *$ & $0.014^{* * *} *$ & $0.009^{*}$ & & 0.019*** \\
\hline & $(0.006)$ & $(0.005)$ & $(0.005)$ & $(0.005)$ & & $(0.005)$ \\
\hline \multirow[t]{2}{*}{ Years of Schooling } & $0.003^{* * *}$ & $0.002^{*} * *$ & $0.003 * * *$ & 0.001 & $0.003^{*} * *$ & \\
\hline & $(0.001)$ & $(0.001)$ & $(0.001)$ & $(0.001)$ & $(0.001)$ & \\
\hline \multirow[t]{2}{*}{ Constant } & $0.860 * * *$ & 0.798**** & $0.820 * * *$ & $0.283^{*} * *$ & $1.066^{* * * *}$ & $0.843^{*} * *$ \\
\hline & $(0.112)$ & $(0.113)$ & $(0.112)$ & $(0.083)$ & $(0.089)$ & $(0.112)$ \\
\hline Observations & 1,310 & 1,312 & 1,310 & 1,322 & 1,310 & 1,310 \\
\hline R-squared & 0.938 & 0.936 & 0.937 & 0.934 & 0.937 & 0.937 \\
\hline Number of countries & 83 & 83 & 83 & 83 & 83 & 83 \\
\hline F-Stat & 17.58 & 15.48 & 23.26 & 9.887 & 18.71 & 18.95 \\
\hline Prob $>$ F & 0.0000 & 0.0000 & 0.0000 & $1.13 \mathrm{e}-10$ & 0.0000 & 0.0000 \\
\hline Country fixed effects & Yes & Yes & Yes & Yes & Yes & Yes \\
\hline
\end{tabular}

Note: standard errors in parentheses $* * * \mathrm{p}<0.01,{ }^{*} * \mathrm{p}<0.05, * \mathrm{p}<0.1$

The result shows that the ECI coefficient is statistically significant at a $1 \%$ level at all models (Table 5). Hence, it confirms previous empirical findings of Hartmann et al. (2017) and Lee and Vu (2020) during 1963-2008 under the fixed-effects estimation, economic complexity is associated with inequality reduction. Ceteris paribus, a one-unit increase in Economic Complexity Index, is associated with a Gini reduction of 0.014 units. 
Secondly, the rule of law and the government's voice and accountability are sound predictors as their magnitudes on the Kuznets Curve and economic complexity. As mentioned earlier, institutions act as a catalyst in economic growth and income distribution. One unit increase in the government's voice and accountability is associated with a 0.011 unit increasing in inequality, holding other variables constant. Also, each additional unit on the rule of law correlates with 0.012 units in inequality reduction. However, variable political stability and the absence of violence/terrorism are not statistically significant unless the model controls GDP per capita.

\subsection{Two-step System GMM}

There are several considerations for using system GMM. First, the Hausman test suggests that the fixed-effects model is more appropriate. Therefore, within-country intercepts biasing the predictors or the outcome need to be controlled. Second, the White test shows heteroscedasticity. Third, this paper suspects autocorrelation is present in the fixed-effects model. Lastly, the Gini outcome variable and GDP seem persistent ${ }^{11}$ and might induce an endogeneity bias problem. Moreover, despite the strong correlation, the OLS and fixed effect estimations do not necessarily imply causality. Therefore, the dynamic data panel equation using a system GMM estimator could be utilized to solve the possible problems (Arellano \& Bover, 1995; Roodman, 2009) and draw a causal impact of economic complexity and institutions on income inequality.

Results from the dynamic panel data model in Equation 8 are presented in Table 6. Firstly, the failure to reject the Hansen $J$ test for over-identification results in $p$-value equals 0.185 . Therefore, the hypothesis implying the instruments are exogenous cannot be rejected. Moreover, the $\mathrm{AR}(2)$ test substantiates the error terms are not serially correlated, implying that the instruments used are consistent (Roodman, 2009).

Table 6. Two-step System GMM Results (Dependent Variable: GINI)

\begin{tabular}{|c|c|c|c|c|c|}
\hline VARIABLES & (1) & (2) & (3) & (4) & $(5)$ \\
\hline \multirow[t]{2}{*}{ Gini $_{t-1}$} & 0.001 & $0.004 * *$ & 0.002 & 0.001 & 0.002 \\
\hline & $(0.002)$ & $(0.001)$ & $(0.002)$ & $(0.001)$ & $(0.001)$ \\
\hline \multirow[t]{2}{*}{ ECI } & $-0.024 * *$ & & -0.017 & $-0.029^{* * * *}$ & -0.031 **** \\
\hline & $(0.011)$ & & $(0.011)$ & $(0.010)$ & $(0.011)$ \\
\hline $\begin{array}{l}\text { Political stability and absence of } \\
\text { violence/terrorism }\end{array}$ & $\begin{array}{l}-0.006 \\
(0.010)\end{array}$ & $\begin{array}{l}-0.003 \\
(0.007)\end{array}$ & & $\begin{array}{l}-0.007 \\
(0.010)\end{array}$ & $\begin{array}{l}-0.008 \\
(0.008)\end{array}$ \\
\hline Per-capita GDP-PPP, log & $\begin{array}{l}-0.094 \\
(0.060)\end{array}$ & $\begin{array}{l}-0.114^{* *} \\
(0.054)\end{array}$ & $\begin{array}{l}-0.099 \\
(0.072)\end{array}$ & & $\begin{array}{l}-0.103 \\
(0.067)\end{array}$ \\
\hline $\begin{array}{l}\text { Per-capita GDP-PPP, log, } \\
\text { squared }\end{array}$ & $\begin{array}{l}0.005 \\
(0.003)\end{array}$ & $\begin{array}{l}0.005^{*} \\
(0.003)\end{array}$ & $\begin{array}{l}0.005 \\
(0.004)\end{array}$ & & $\begin{array}{l}0.005 \\
(0.004)\end{array}$ \\
\hline \multirow[t]{2}{*}{ Years of schooling } & -0.003 & -0.003 & -0.004 & -0.004 & \\
\hline & $(0.005)$ & $(0.004)$ & $(0.004)$ & $(0.005)$ & \\
\hline Constant & $0.871^{* * * *}$ & $0.878^{* * * *}$ & $0.886^{* *}$ & 0.421 **** & $0.843^{* * *}$ \\
\hline
\end{tabular}

\footnotetext{
${ }^{11}$ We use lags 2 for $\log$ natural of GDP and its squared terms based on the rule-of-thumb for endogeneous variables, see (Roodman, 2009).
} 


\begin{tabular}{|l|c|c|c|c|c|}
\hline & $(0.316)$ & $(0.280)$ & $(0.355)$ & $(0.086)$ & $(0.323)$ \\
\hline Time Fixed Effects & Yes & Yes & Yes & Yes & Yes \\
\hline Observations & 1,146 & 1,148 & 1,146 & 1,157 & 1,146 \\
\hline Instruments/Groups & $71 / 81$ & $68 / 81$ & $68 / 81$ & $65 / 81$ & $43 / 82$ \\
\hline $\operatorname{AR}(1)(p$ value $)$ & 0.077 & 0.015 & 0.068 & 0.058 & 0.051 \\
\hline $\operatorname{AR}(2)(p$ value $)$ & 0.655 & 0.311 & 0.550 & 0.593 & 0.522 \\
\hline Hansen test $(p$ value $)$ & 0.185 & 0.036 & 0.191 & 0.096 & 0.090 \\
\hline F-stat & 954.3 & 916.3 & 1080 & 1186 & 883 \\
\hline
\end{tabular}

Note: We assume that ECI, political stability, GDP, and education are endogenous.

Standard errors in parentheses $* * * \mathrm{p}<0.01, * * \mathrm{p}<0.05, * \mathrm{p}<0.1$

Secondly, the main findings of Equation 8 in Table 6 column 1 imply that the estimated coefficient of lagged-Gini has a positive sign and is not statistically significant. This result contradicts the previous finding of Lee \& Vu (2020) that income inequality has time persistence so that its lagged variable is highly significant.

Our preferred method, two-step system GMM estimation, indicated negative relationships between economic complexity and institutions as predictors of inequality. We assume that economic complexity, political stability, GDP per capita, and education are also endogenous. Thus, we found evidence of a causal link between economic complexity and inequality reduction. Furthermore, the estimated coefficient sign of the economic complexity contradicts Lee \& Vu's previous work (2020) that suggests economic complexity provokes a wider income gap.

Any immediate increasing unit of the economic complexity index provokes 0.024 units of inequality reduction $(\mathrm{p}<0.05)$. Even though we do not find any significant impact of political stability on inequality reduction, economic complexity is only significant if we include variable political stability (6.4 column 3). Our findings suggest that productive structures affect equal income distribution. The previous literature opposes that countries' advancement in producing sophisticated goods entails wider inequality (Hartmann, 2014). However, the government's political stability and absence of terrorism might explain income distributions through an ideal setting for inclusive development.

What differentiates developing countries developed is the resources endowment and the disparity in knowledge and institutions (Dahlman et al., 1998). Workers in more advanced countries have less risk compared to those in less developed countries. A high level of education, accumulated know-how, and transferable skills enable them to adjust to structural change. In addition, developed countries tend to have relatively stable political frameworks. This condition might govern the rule of law, property rights, national security, and investment in education (Artadi \& Sala-i-Martin, 2003). In other words, the country's settings promote inequality reduction.

In contrast, economic development in under-developed countries usually faces wars, violence, or terrorism. Therefore, given any productive development, inequality could be reduced since the government cannot provide better services or provide essential income distribution policies. Also, as mentioned earlier, weak ordinance, ethnics fragmentation, demonstrations, military coup, or terrorism lead to a disrupted economy, exacerbating the income gap (Acemoglu et al., 2012; Collier \& Gunning, 1999; Easterly \& Levine, 1997; Rodrik, 2002). 


\section{Conclusions and Recommendation}

This study puts economic complexity along with institutions in an attempt to explain income inequality. It uses OLS regression, and fixed effects estimate regression and a dynamic panel data model. The OLS estimates suggest that economic complexity, government accountability, political stability, and law rule negatively correlate with the country's income gap and are significant determinants. To eliminate countries' individual effects, fixed effects estimates result in similar conclusions. However, given the possible endogeneity bias problem, a dynamic panel data model is estimated using the two-step system GMM. The latest model only uses political stability and the absence of violence and terrorism as an institutional indicator.

The main finding in economic complexity resembles the OLS and fixed-effects regression results. We find evidence political of a causal impact of economic complexity on income inequality reduction. Meanwhile, political stability and the absence of violence or terrorism are not significant. It is in line with previous research findings that governance indicators, including secured political framework, are not significant (Hartmann et al., 2017). Conclusively, this study reaffirms previous studies suggesting economic complexity is a sound predictor for income inequality ( Hartmann et al., 2017; Lee \& Vu, 2020).

The results, as mentioned earlier, give important insight into the correlation of countries' productive structures and the type of institutions' performance on incubating income distribution. Firstly, behind the advancement phase of countries' productive structures in tradeable goods, firms and the higher class exploit the chance, maximizing their utility and growing. The government's chance might be provided and manifested as trade openness, ease of doing business, and transparency and bureaucracy. The economy, as a result, grows. Thus, it grows bigger while people from the below classes obtain the economic premium from the productive structures. This sequential notion also confirms the Kuznets Curve that, in the meantime, the income gap increases before it eventually reduces (Kuznets, 1955). Ultimately, policymakers might consider inclusive economic policies, the rule of law, and political stability that migth stimulate growth and promote other sectors with less productivity per capita.

This panel data study encounters limitations and only justifies causal inference based on assumptions mentioned earlier. Even though the study tries to solve the endogeneity bias problem by treating regressors as endogenous variables, independent variables are associated with income inequality and are not covered in this study. Thus, this study might have omitted the variable bias problem, a potential cause of the endogeneity problem. Future research might consider these problems and add more observation in designing experimental research to capture a better generalization.

\section{References}

Acemoglu, D., Gallego, F. A., \& Robinson, J. A. (2014). Institutions, human capital, and development. Annual Review of Economics, 6(1), 875-912.

Acemoglu, D., Johnson, S., \& Robinson, J. A. (2001). The colonial origins of comparative development: An empirical investigation. The American Economic Review, 91(5), 13691401 .

Acemoglu, D., \& Robinson, J. A. (2012). Why nations fail: The origins of power, prosperity, and poverty. Currency.

Ahluwalia, M. S. (1976). Income distribution and development: Some stylized facts. The American Economic Review, 66(2), 128-135. 
Arellano, M., \& Bond, S. (1991). Some tests of specification for panel data: Monte Carlo evidence and an application to employment equations. The Review of Economic Studies, 58(2), 277-297.

Arellano, M., \& Bover, O. (1995). Another look at the instrumental variable estimation of error components models. Journal of Econometrics, 68(1), 29-51.

Artadi, E. V., \& Sala-i-Martin, X. (2003). The economic tragedy of the XXth century: Growth in Africa (No. w9865). National Bureau of Economic Research.

Audi, M., \& Ali, A. (2017). Exploring the Linkage between corruption and economic development in case of selected developing and developed nations. Munich Personal RePEc Archive, 83158.

Barro, R. J. (2008). Inequality and growth revisited (No. 11). ADB working paper series on regional economic integration.

Bates, R. H. (2013). The Imperial Peace in Colonial Africa and Africa's Underdevelopment. Africa's Development in Historical Perspective, Cambridge: Cambridge University Press, forthcoming.

Blundell, R., \& Bond, S. (1998). Initial conditions and moment restrictions in dynamic panel data models. Journal of Econometrics, 87(1), 115-143.

Bond, S. R. (2002). Dynamic panel data models: a guide to micro data methods and practice. Portuguese Economic Journal, 1(2), 141-162.

Bourguignon, F. (2004). The poverty-growth-inequality triangle (No. 125). working paper.

Bustos, S., Gomez, C., Hausmann, R., \& Hidalgo, C. A. (2012). The dynamics of nestedness predicts the evolution of industrial ecosystems. PloS One, 7(11), e49393.

Caldarelli, G., Cristelli, M., Gabrielli, A., Pietronero, L., Scala, A., \& Tacchella, A. (2012). A network analysis of countries' export flows: firm grounds for the building blocks of the economy. PloS One, 7(10), e47278.

Collier, P., \& Gunning, J. W. (1999). Why has Africa grown slowly?. Journal of Economic Perspectives, 13(3), 3-22.

Deininger, K., \& Squire, L. (1998). New ways of looking at old issues: inequality and growth. Journal of Development Economics, 57(2), 259-287.

Duflo, E. (2004). The medium-run effects of educational expansion: Evidence from a large school construction program in Indonesia. Journal of Development Economics, 74(1), 163-197.

Easterly, W., \& Levine, R. (1997). Africa's growth tragedy: policies and ethnic divisions. The Quarterly Journal of Economics, $112(4), 1203-1250$.

Engerman, S. L., \& Sokoloff, K. L. (1994). Factor endowments: institutions, and differential paths of growth among new world economies. National Bureau of Economic Research.

Galbraith, J. K., Halbach, B., Malinowska, A., Shams, A., \& Zhang, W. (2014). UTIP global inequality data sets 1963-2008: Updates, revisions, and quality checks. The University of Texas working paper.

Glaeser, E. L., La Porta, R., Lopez-de-Silanes, F., \& Shleifer, A. (2004). Do institutions cause growth?. Journal of Economic Growth, 9(3), 271-303.

Goodman, B., \& Hirschman, A. O. (1959). The Strategy of Economic Development. Journal of Farm Economics, 41(2), 468.

Guo, G. (2009). China's local political budget cycles. American Journal of Political Science, 53(3), 621-632. 
Hall, R. E., \& Jones, C. I. (1999). Why do some countries produce so much more output per worker than others?. The Quarterly Journal of Economics, 114(1), 83-116.

Hartmann, D. (2014). Economic complexity and human development: How economic diversification and social networks affect human agency and welfare. Taylor \& Francis.

Hartmann, D., Guevara, M. R., Jara-Figueroa, C., Aristarán, M., \& Hidalgo, C. A. (2017). Linking economic complexity, institutions, and income inequality. World Development, 93, 75-93.

Harvard's Growth Lab. (n.d.). Japan's Export Complexity. The Atlas of Economic Complexity. https://atlas.cid.harvard.edu/countries/114/ export-complexity.

Hausmann, R., Hidalgo, C. A., Bustos, S., Coscia, M., \& Simoes, A. (2014). The atlas of economic complexity: Mapping paths to prosperity. MIT Press.

Hidalgo, C. A., \& Hausmann, R. (2009). The building blocks of economic complexity. Proceedings of the national academy of sciences, 106(26), 10570-10575.

Hidalgo, C. A., Klinger, B., Barabási, A. L., \& Hausmann, R. (2007). The product space conditions the development of nations. Science, 317(5837), 482-487.

Jones, B. F., \& Olken, B. A. (2005). Do leaders matter? National leadership and growth since World War II. The Quarterly Journal of Economics, 120(3), 835-864.

Judson, R. A., \& Owen, A. L. (1999). Estimating dynamic panel data models: a guide for macroeconomists. Economics Letters, 65(1), 9-15.

Kanbur, R. (2012). Does Kuznets still matter?. Working paper.

Kaufmann, D., Kraay, A., \& Mastruzzi, M. (2009). Governance matters VIII: aggregate and individual governance indicators, 1996-2008. World Bank Policy Research working paper, (4978).

Khan, H., Khan, U., \& Khan, M. A. (2020). Causal nexus between economic complexity and FDI: Empirical evidence from time series analysis. The Chinese Economy, 53(5), 374394.

Kim, D. H., Hsieh, J., \& Lin, S. C. (2019). Financial liberalization, political institutions, and income inequality. Empirical Economics, 1-37.

Knack, S., \& Keefer, P. (1995). Institutions and economic performance: cross-country tests using alternative institutional measures. Economics \& Politics, 7(3), 207-227.

Kuznets, S. (1955). Economic growth and income inequality. American Economic Review, $45(2), 1-28$.

Lee, K. K., \& Vu, T. V. (2019). Economic complexity, human capital, and income inequality: a cross-country analysis. The Japanese Economic Review, 1-24.

Nickell, S. (1981). Biases in dynamic models with fixed effects. Econometrica: Journal of the Econometric Society, 1417-1426.

North, D. C. (1990). Institutions, institutional change, and economic performance. Cambridge University Press.

North, D. C., \& Thomas, R. P. (1973). The rise of the western world: A new economic history. Cambridge University Press.

Perotti, R. (1996). Democracy, income distribution, and growth: What the data say. Journal of Economic Growth, 1(2), 149-187.

Rodrik, D. (2003). Institutions, integration, and geography: In search of the deep determinants of economic growth. In Search of Prosperity: Analytic Country Studies on Growth. Princeton University Press. 
Romer, D., \& Chow, C. (1996). Advanced macroeconomic theory. McGraw-Hill. Shapiro, MD

Romer, P. M. (1990). Endogenous technological change. Journal of Political Economy, 98(5, Part 2), S71-S102.

Roodman, D. (2009). How to do xtabond2: An introduction to difference and system GMM in Stata. The Stata Journal, 9(1), 86-136.

Sachs, J. D., \& Warner, A. M. (1997). Fundamental sources of long-run growth. The American Economic Review, 87(2), 184-188.

Saviotti, P. P., Pykaa, A., \& Jun, B. (2020). Diversification, structural change, and economic development. Journal of Evolutionary Economics, 30, 1301-1335.

Simoes, A. J. G., \& Hidalgo, C. A. (2011, August). The economic complexity observatory: An analytical tool for understanding the dynamics of economic development. In workshops at the twenty-fifth AAAI conference on artificial intelligence.

Stiglitz, J. E. (1996). Some lessons from the East Asian miracle. The World Bank Research Observer, $11(2), 151-177$.

Stiglitz, J. E. (2018). From manufacturing-led export growth to a twenty-first-century inclusive growth strategy: Explaining the demise of a successful growth model and what to do about it (No. 2018/176). WIDER working paper.

Stiglitz, J., Sen, A., \& Fitoussi, J. P. (2009). The measurement of economic performance and social progress revisited. Reflections and overview. Commission on the measurement of economic performance and social progress, Paris.

Wan, G., Wang, C., \& Zhang, X. (2021). The Poverty-Growth-Inequality Triangle: Asia 1960 s to 2010 s. Social Indicators Research, 153(3), 795-822.

Wooldridge, Jeffrey M. 2010. Econometric analysis of cross-section and panel data (2 ed.). MIT Press. 